\title{
EVALUASI STATUS GIZI PEREMPUAN PESISIR DESA REBO KABUPATEN BANGKA
}

\author{
Fika Dewi Pratiwi ${ }^{a} *$, Sudirman Adibrata ${ }^{a}$, Wahyu Adi ${ }^{a}$ \\ aProgram Studi Manajemen Sumberdaya Perairan, Fakultas Pertanian, Perikanan dan Biologi, \\ Universitas Bangka Belitung, Provinsi Kepulauan Bangka Belitung \\ *Koresponden penulis: fikapratiwi.12@gmail.com
}

\begin{abstract}
Abstrak
Perempuan memiliki peran penting di dalam keluarga dan masyarakat pesisir. Status gizi perempuan dewasa merupakan salah satu penentu lahirnya generasi bangsa yang berkualitas. Status gizi dapat dianalisis dengan nilai BMI (Body Mass Index), yang dipengaruhi oleh faktor internal maupun eksternal. Berdasarkan hal tersebut penelitian ini bertujuan untuk menganalisis status gizi perempuan dewasa di pesisir Desa Rebo, Kabupaten Bangka dan menganalisis faktor yang mempengaruhi status gizi perempuan dewasa di pesisir Desa Rebo, Kabupaten Bangka terkait dengan kondisi sosial ekonomi (tingkat pendapatan, tingkat pendidikan, aktivitas harian). Penelitian lapangan (field research) ini dilaksanakan pada bulan Mei-Agustus 2020. Sampel penelitian ditentukan secara purposive sampling yaitu 120 responden perempuan dari populasi perempuan yang berasal dari dusun berbeda di Desa Rebo (dusun Rebo 1057 jiwa, dusun Karang Panjang 185 jiwa dan dusun Tanjung Ratu 835 jiwa). Pengambilan data status gizi dan kondisi sosial ekonomi menggunakan kuesioner tertutup. Nilai BMI menunjukkan 72 orang perempuan dewasa memiliki berat badan ideal, sedangkan 48 orang adalah tidak ideal. Hasil analisis chi-square menunjukkan bahwa tingkat pendidikan dan tingkat aktivitas memiliki pengaruh terhadap nilai BMI atau status gizi perempuan dewasa di pesisir Desa Rebo, sedangkan tingkat pendapatan tidak berpengaruh terhadap nilai BMI. Penelitian lanjutan dapat dilakukan dengan mengkaji pola konsumsi makanan dan status kesehatan dari perempuan dewasa. Hasil penelitian yang diperoleh dapat dijadikan landasan untuk membuat kebijakan atau program untuk meningkatkan kesejahteraan keluarga pesisir Desa Rebo, yang berdampak pada kemampuan akses ragam dan mutu pangan harian yang berkualitas.
\end{abstract}

Kata kunci: Gizi, Masyakat Pesisir, Perempuan

\begin{abstract}
Women have an important role in the coastal community's family. The nutritional status of adult women is one of the determinants of the birth of a qualified national generation. Nutritional status can be analyzed by the BMI (Body Mass Index) value, which is influenced by internal and external factors. This study aimed to analyze the nutritional status of adult women on the coast of Rebo Village, Bangka Regency and to analyze the factors affecting the nutritional status of adult women on the coast of Rebo Village, Bangka Regency related to socio-economic conditions (income level, education level, daily activities). This field research was conducted in May-August 2020. The research sample was determined by purposive sampling, 120 female respondents who came from different hamlets in Rebo village. Collecting data on nutritional status and socioeconomic conditions using a closed questionnaire. The BMI value showed that 72 adult women have ideal body weight, while 48 people were not ideal. The results of the chi-square analysis showed that the level of education and the level of activity have an influence on the BMI value of adult women, while the income level does not affect the BMI value. Further research can be carried out by examining the dietary consumption patterns and health status of adult women. The results obtained can be used as a basis for making policies or programs to improve the welfare of coastal families in Rebo village, which have an impact on the ability to access the variety and quality of daily food.
\end{abstract}

Key Words: Nutrient, Coastal community, Woman 


\section{PENDAHULUAN}

Desa Rebo merupakan wilayah pesisir yang secara administratif masuk ke dalam wilayah Kabupaten Bangka, Provinsi Kepulauan Bangka Belitung. Peneliti [1] menyatakan bahwa masyarakat yang tinggal di kawasan pesisir, terbiasa melakukan aktivitas sosial ekonomi dengan memanfaatkan kekayaan sumberdaya perikanan dan kelautan yang ada. Masyarakat pesisir, termasuk pesisir Desa Rebo, memiliki identitas dan karakteristik yang khas, diantaranya adalah ketergantungan pada kondisi lingkungan, ketergantungan pada musim serta ketergantungan pada pasar. Pada umumnya, masyarakat pesisir memiliki level pendidikan yang rendah. Implikasi dari kondisi tersebut, salah satunya dalah tingkat kesejahteraan keluarga pesisir dikategorikan rendah [2]. Rendahnya tingkat kesejahteraan masyarakat sering kali berdampak pada kesulitan akses ragam dan mutu pangan harian yang dapat mempengaruhi asupan nutrisi individu keluarga. Hal tersebut tentu saja dapat berdampak pada derajat kesehatan individu dalam keluarga, baik pada ibu, bapak maupun anak dalam suatu keluarga masyarakat pesisir.

Ragam dan mutu pangan harian bukanlah hal yang prioritas bagi masyarakat pesisir, khususnya bagi perempuan dewasa, yang memiliki peran sebagai ibu. Hal tersebut seringkali luput dari perhatian keluarga masyarakat pesisir. Padahal, asupan gizi seorang ibu merupakan hal yang sangat menentukan lahirnya generasi bangsa yang sehat dan berkualitas. Generasi yang sehat dan berkualitas, merupakan aspek penting yang ingin dicapai dalam pembangunan keluarga yang mendukung pembangunan nasional berkelanjutan [3]. Menangapi hal tersebut, pemerintah juga telah berupaya melakukan berbagai program untuk meningkatkan ketahanan pangan keluarga, termasuk masyarakat pesisir di berbagai wilayah Indonesia. Isu ketahanan pangan yang mencakup keterjangkauan akses masyarakat termasuk masyarakat pesisir terhadap ragam dan mutu pangan juga merupakan salah satu dari 26 program prioritas yang ditetapkan oleh Kementrian Koordinator Bidang Perekonomian pada tahun 2020 [4].

Berdasarkan permasalahan yang seringkali ditemukan pada masyarakat pesisir, penelitian yang spesifik mengkaji mengenai status gizi perempuan pesisir Desa Rebo, belum pernah dilakukan. Oleh karena itu, peneliti tertarik melakuan kajian evaluasi status gizi perempuan dewasa pesisir Desa Rebo, Kabupaten Bangka. Penelitian ini bertujuan untuk menganalisis status gizi perempuan dewasa di pesisir Desa Rebo, Kabupaten Bangka dan menganalisis faktor yang mempengaruhi status gizi perempuan dewasa di pesisir Desa Rebo, Kabupaten Bangka terkait dengan kondisi sosial ekonomi (tingkat pendapatan, tingkat pendidikan, aktivitas harian). Penelitian tersebut penting dilakukan karena hasil penelitian akan memberikan informasi dasar mengenai kondisi perempuan dewasa pesisir Desa Rebo, sehingga dapat dijadikan landasan dalam memformulasikan strategi atau kebijakan pemerintah setempat terkait kondisi masyarakat pesisir Desa Rebo, kabupaten Bangka.

\section{METODE}

\section{Metode Pengumpulan Data}

Penelitian yang bersifat lapangan (field research) ini dilaksanakan pada bulan Mei sampai dengan sampai dengan Agustus 2020. Evaluasi status gizi perempuan di wilayah pesisir pantai Rebo, Kabupaten Bangka (Gambar 1) dilakukan pada tiga lokasi yang berbeda dengan objek perempuan dewasa yang berasal dari dusun Rebo, dusun Tanjung Ratu dan dusun Karang Panjang yang masuk ke dalam wilayah pesisir pantai Rebo. Sampel penelitian ditentukan secara purposive sampling, sedangkan data penelitian diperoleh melalui metode pemberian kuesioner kepada responden. Berdasarkan data Desa Tahun 2019, jumlah populasi perempuan yang berasal dari dusun berbeda di Desa Rebo adalah dusun Rebo 1057 jiwa, dusun Karang Panjang 185 jiwa dan dusun Tanjung Ratu 835 jiwa. Oleh karena itu, sampel responden yang dipilih berjumlah 120 responden perempuan yang mewakilli tiga dusun berbeda di di Desa Rebo, dengan harapan dapat merepresentasikan status gizi perempuan dewasa di lokasi penelitian. 


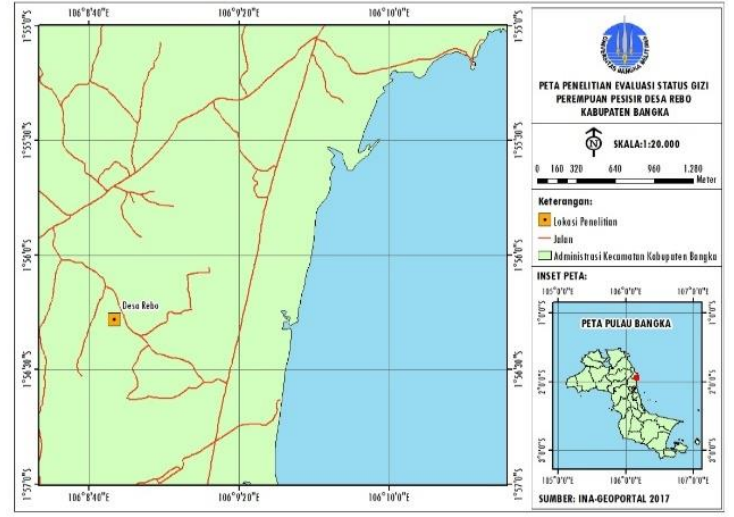

Gambar 1. Wilayah Pesisir Desa Rebo Sumber: [5]

\section{Metode Analisis Data}

Pada penelitian ini, analisis status gizi individu perempuan dewasa pesisir Desa Rebo menggunakan metode BMI (Body Mass Index) berdasarkan WHO. BMI didefinisikan sebagai berat tubuh manusia dalam kilogram dibagi dengan kuadrat tinggi manusia dalam meter $\left(\mathrm{kg} / \mathrm{m}^{2}\right)$. Analisis deskriptif digunakan untuk merepresentasikan distribusi frekuensi berupa jumlah maupun persentase. Analisis keterkaitan antara variabel dependen yaitu BMI dengan salah satu variabel independen (tingkat pendapatan, tingkat pendidikan dan tingkat aktivitas) dalam penelitian ini digunakan uji Chi-square dengan SPSS.

\section{HASIL DAN PEMBAHASAN}

Wilayah pesisir Desa Rebo, terdiri atas tiga dusun berbeda. Mayoritas penduduknya bermata pencaharian sebagai nelayan. Kaum laki-laki biasanya melaut untuk mencari ikan, dan sebagian kecil ada yang menambang timah, sedangkan kaum perempuan mayoritas berperan sebagai ibu rumah tangga. Berkaitan dengan mata pencaharian nelayan yang sangat bergantung pada alam, maka pendapatan yang mereka peroleh tidak pasti setiap waktunya. Berdasarkan hasil penelitian, pendapatan keluarga responden penelitian adalah tinggi, berkisar antara satu sampai dengan lima juta per bulan. Namun, peneliti lain [6] menyatakan bahwa biasanya nelayan akan cepat menghabiskan uang yang didapatkannya dari hasil melaut. Berdasarkan kondisi pendapatan keluarga pesisir, kemungkinan masyarakat pesisir beresiko kesulitan akses ragam dan mutu pangan harian yang berkualitas, bahkan bisa mengalami malnutrisi [7]. Padahal, kuantitas dan kualitas makanan yang dikonsumsi sangat menentukan status gizi seseorang. Penetapan status gizi adalah hal penting dilakukan terkait dengan kesehatan individu dalam suatu komunitas [8].

BMI adalah indikator yang baik untuk menetapkan status gizi dari seseorang [9]. BMI menunjukkan ukuran kondisi seorang individu kekurangan atau kelebihan nutrisi yang dibutuhkan oleh tubuh. Pada penelitian ini, objek penelitian yaitu status gizi perempuan dewasa pesisir Desa Rebo. Berdasarkan hasil penelitian (Gambar 2) diperoleh 72 dari 120 orang responden memiliki BMI yang ideal atau berdasarkan standar WHO [10] memiliki BMI dengan rentang $18.5-24.9 \mathrm{~kg} / \mathrm{m}^{2}$, sedangkan sisanya dikategorikan tidak ideal yang berarti kurus, kelebihan berat badan sampai dengan obesitas. Hasil yang sedikit berbeda dikemukakan oleh Seorang peneliti [11] mengkaji status nutrisi dari komunitas nelayan yang dilakukan di Bengal, India, yang menunjukkan bahwa masyarakatnya kurang mampu untuk memenuhi kebutuhan minimum makanan dan minuman. Peneliti lain [12] menyampaikan hasil penelitiannya bahwa asupan makanan yang tidak mencukupi bagi nelayan perempuan, dinyatakan sebagai kelaparan yang tersembunyi karena seringkali luput dari perhatian.

Kondisi status gizi perempuan dewasa pesisir Desa Rebo tersebut biasanya dipengaruhi beberapa faktor. Status gizi perempuan dewasa yang tidak berimbang dapat menyebabkan berat badan tidak ideal, dapat dipengaruhi oleh status perkawinan, tingkat pendapatan, tingkat pendidikan, lokasi tempat tinggal maupun aktivitas fisik yang dilakukan [13]. Pada penelitian ini, faktor yang dikaji pengaruhnya terhadap status gizi perempuan dewasa pesisir Desa Rebo adalah tingkat pendidikan, tingkat aktivitas dan tingkat pendapatan dalam keluarga. Berdasarkan uji chi-square (Tabel 1) diperoleh bahwa terdapat hubungan antara level pendidikan dan aktivitas perempuan terhadap BMI perempuan dewasa pesisir Desa Rebo, sedangkan sebaliknya tidak terdapat hubungan antara tingkat pendapatan dengan nilai BMI perempuan dewasa. Pada tabel 1 juga menunjukkan bahwa hampir sebagian besar responden yang memiliki level pendidikan 
dasar yaitu SD dan SMP, tercatat memiliki BMI ideal atau normal. Hal yang lain yang dapat ditunjukkan yaitu responden dengan pendidikan tinggi yaitu SMA sampai dengan perguruan tinggi justru didapati BMI tidak ideal (kurus sampai dengan berlebih).

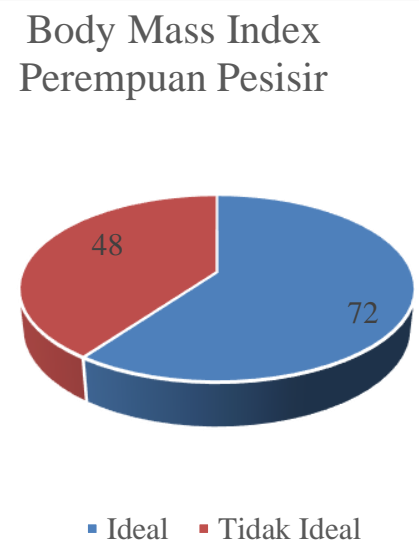

Gambar 2. BMI Perempuan Dewasa

Tabel 1. Hubungan status gizi, pendidikan, aktifitas dan pendapatan

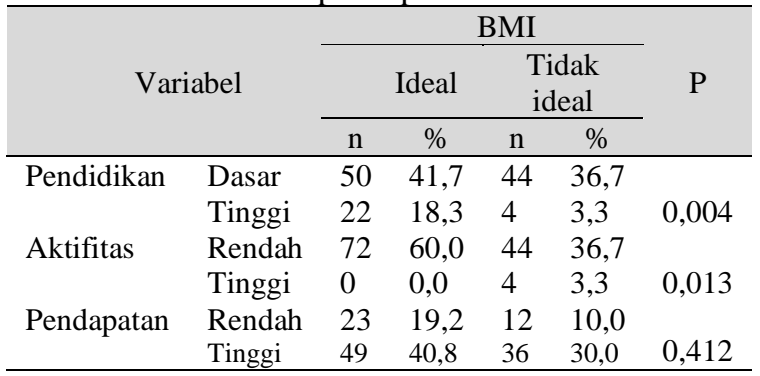

Hasil penelitian juga menunjukkan bahwa perempuan dengan tingkat aktivitas rendah atau berperan sebagai ibu rumah tangga yang tidak bekerja di luar rumah, memiliki berat badan yang ideal atau normal dari pada yang memiliki aktivitas tinggi atau bekerja di luar rumah. Hal tersebut menunjukkan bahwa meskipun pendidikan tinggi dan aktivitas tinggi, namun terdapat faktor lain mungkin lebih mempengaruhi nilai BMI perempuan dewasa. Faktor lain yang dimaksud adalah faktor internal individu berupa faktor genetik dan juga pola konsumsi makanan [14]. Pola konsumsi makanan yang tidak sehat seperti mengkonsumsi makanan siap saji juga dapat menjadi penyebab kelebihan berat badan dari seseorang [15].

Hasil penelitian yang diperoleh dapat menggambarkan kondisi status gizi dari perempuan pesisir Desa Rebo, dan dapat dijadikan dasar untuk membuat kebijakan atau program yang ditujukan untuk meningkatkan kesejahteraan keluarga nelayan sehingga bisa meningkatkan kemampuan akses ragam dan mutu pangan harian yang berkualitas. Penelitian lanjutan terkait dengan pola konsumsi makanan harian dan kondisi kesehatan yang dapat mempengaruhi status gizi perempuan dewasa pesisir Desa Rebo dapat dilakukan untuk melengkapi penelitian yang sudah dilakukan.

\section{KESIMPULAN}

Kesimpulan yang dapat dituliskan dari hasil penelitian ini adalah bahwa nilai body mass index (BMI) perempuan dewasa di pesisir Desa Rebo 72 orang ideal dan 48 orang tidak ideal. Faktor yang mempengaruhi nilai BMI adalah tingkat pendidikan dan tingkat aktivitas, sedangkan tingkat pendapatan tidak mempengaruhi nilai BMI perempuan dewasa di pesisir Desa Rebo.

\section{UCAPAN TERIMA KASIH}

Penulis mengucapkan terimakasih banyak kepada Universitas Bangka Belitung, yang telah memberikan dana penelitian dosen tingkat jurusan untuk dapat menyelesaikan penelitian ini, serta semua pihak yang membantu pelaksanaan penelitian sampaik dengan selesai.

\section{DAFTAR PUSTAKA}

[1] I. Indarti \& Y. Kuntari. 2015. Model Pemberdayaan Sumberdaya masyarakat Pesisir melalui Re-engineering Ekonomi Berbasis Koperasi Berkelanjutan. Prosiding Seminar Nasional Multidisiplin Ilmu dan Call For Paper UNISBANK (SENDI_U). Kajian Multidisiplin Ilmu untuk Mewujudkan Poros Maritim dalam Pembangunan Ekonomi Berbasis Kesejahteraan Rakyat. ISBN: 978-979-3649-81-8.

[2] Kismartini \& B Bungin. 2019. Wilayah Pesisir Indonesia (Narasi Kebijakan Publik, Masalah Pesisir dan Pulaupulau Kecil di Indonesia). Prenada Media Group. Jakarta 
[3] Pemerintah Republik Indonesia. 2009. Undang-undang No.52 Tahun 2009. Perkembangan Kependudukan dan Pembangunan Keluarga. Jakarta

[4] https://www.aa.com.tr/id/ekonomi/indo nesia-tetapkan-26-program-prioritastahun-2020/1514791, (akses 24 September 2020)

[5] Desa Rebo. 2020. www.google.com (akses 24 September 2020)

[6] D. Sarah.2017.Kemiskinan \& Nelayan Tradisional Di Kecamatan Medan Belawan Kota Medan. Seminar Nasional Multidisiplin Ilmu. DOI: 10.31219/osf.io/znw5v

[7] S.R.B. French 2013.Food security and nutritional status in fishing communities in Bolivia's Northern Amazon: results of a household survey. Thesis. University of British Columbia

[8] S.R Shrivastava, P.S Shrivastava \& J Ramasamy.2014. Assessment of Nutritional Status in the Community and Clinical Settings. SHORT COMMUNICATION. J Med Sci J Med Sci. 34(5), 211-213

[9] B Pal, B Seal \& $\quad$ S.K Roy.2014.Nutritional status of Fishermen Communities: validation of conventional methods with discriminant function analysis. Bulletin of Mathematical Sciences and Applications. 8:49-59. ISSN: 22789634,

doi:10.18052/www.scipress.com/BMS

A.8.49 2014 SciPress Ltd, Switzerland

[10] C. Nishida. 2004. Appropriate bodymass index for Asian populations and its implications for policy and intervention strategies. THE LANCET. 363:157-63. www.thelancet.com

[11] B Pal, M Chattopadhyay, M Maity, B Mukhopadhyay \& R Gupta.2010. Income and nutritional status of the fishing community residing in coastal Bay of Bengal: a case study. Anthropol
Anz.68 (2), 195-208. doi: 10.1127/0003$5548 / 2011 / 0098$.

[12] K. Kumarakuru \& H Sundaramoorthy.2015. Nutritional Status and Dietary Pattern of Fisher Women in Puducherry.The Indian Journal of Nutrition and Dietetics. 52:3

[13] R. Diana, I Yuliana, G Yasmin, \& Hardinsyah. 2013. Faktor Risiko Kegemukan pada Wanita Dewasa Indonesia. Jurnal Gizi dan Pangan.8 (1), 1-8. ISSN 1978 - 1059

[14] K Omage \& V.O Omuemu. 2018. Assessment of Dietary Pattern and Nutritional Status of Undergraduate Student in a Private University in Southern Nigeria. Food Science and Nutrition. 6(7), 1890-1897

[15] A.A.I.M. Paramitya \& T.D Valentina.2014. Hubungan Regulasi Diri Dengan Status Gizi pada Remaja Akhir di Kota Denpasar. Jurnal Psikologi Udayana. 1(1), 43-53 